\title{
PHYSICAL AND MECHANICAL PROPERTIES OF ORIENTED WOOD- CEMENT BOARDS PRODUCED WITH FIVE EUCALYPTUS SPECIES
}

\author{
Thiago Souza da Rosa ${ }^{1 *}$, Vinícius Rosa Schweitzer ${ }^{1}$, Rosilani Trianoski $^{2}$, Setsuo Iwakiri ${ }^{2}$ \\ ${ }^{1}$ Universidade Federal do Paraná, Programa de Pós-Graduação em Engenharia Florestal, Curitiba, Paraná, Brasil - \\ thiagosouzadarosa@gmail.com*; florestalvinicius@gmail.com \\ ${ }^{2}$ Universidade Federal do Paraná, Departamento de Engenharia e Tecnologia Florestal, Curitiba, Paraná, Brasil - rosilani@ufpr.br; \\ setsuo@ufpr.br
}

Recebido para publicação: 20/02/2017 - Aceito para publicação: 23/08/2017

\begin{abstract}
This study aimed to manufacture oriented wood-cement boards using five Eucalyptus species and mixture between then, to compare the effect of the particles orientation, and to evaluate the physical and mechanical properties according to competent standards. The species studied were: Eucalyptus benthamii, Eucalyptus dunni, Eucalyptus grandis, Eucalyptus saligna, Eucalyptus urograndis the mixture between them and the Pinus taeda as control. The bonding agent employed was commercial grade Portland cement types CP II-Z32R. The panels had dimensions of $48 \times 48 \times 1.2 \mathrm{~cm}$ and nominal specific mass of $1.2 \mathrm{~g} / \mathrm{cm}^{3}$. The cement/wood/water mass ratio used was $2.5: 1: 1$ and $2 \%$ of $\mathrm{CaCl}_{2}$ by weight of cement was used as an additive. The orientation of strands did not influence the dimensional stability properties. All boards had very low IB strength, being that, none treatments reached the requirements to internal bond of competent standards. The MOR and MOE results indicated that species mixture can be obtained boards with properties similar to pure species. In general, the boards showed low mechanical strength what can be attributed to particles geometry and wood-cement ratio. The wood of Eucalyptus species presents potential for use in cement-wood panels.
\end{abstract}

Keywords: Mineral panels; fast growing species; oriented particles.

\section{Resumo}

Propriedades físicas e mecânicas de painéis cimento-madeira orientados produzidos com cinco espécies de Eucalyptus. O objetivo deste estudo foi produzir painéis cimento-madeira orientados usando cinco espécies de Eucalyptus e a mistura entre elas, comparar o efeito da orientação das partículas e avaliar as propriedades físicas e mecânicas de acordo com as normas competentes. As espécies estudadas foram: Eucalyptus benthamii, Eucalyptus dunni, Eucalyptus grandis, Eucalyptus saligna, Eucalyptus urograndis a mistura entre elas e o Pinus taeda como testemunha. Como agente de ligação foi utilizado o cimento Portland comercial do tipo CP II-Z-32R. Os painéis foram produzidos com dimensões de 48 x 48 x 1,2 cm e densidade nominal de $1,2 \mathrm{~g} / \mathrm{cm}^{3}$. A relação cimento/madeira/água utilizada foi de $2,5: 1: 1$ e utilizou-se como aditivo $2 \%$ de $\mathrm{CaCl}_{2}$ em peso de cimento. A orientação das partículas não influenciou as propriedades de estabilidade dimensional. Todos os painéis apresentaram ligação interna baixa, sendo que nenhum dos tratamentos atingiu os requisitos mínimos das normas competentes. Os resultados de MOR e MOE indicaram com a mistura de espécies podese produzir painéis com propriedades semelhantes que aqueles produzidos com espécies puras. Em geral, os painéis apresentaram baixa resistência mecânica sendo atribuído à geometria das partículas e à razão cimentomadeira. A madeira de espécies de eucalipto apresenta potencial para uso em painéis de cimento-madeira. Palavras-chave: Painéis minerais; espécies de rápido crescimento; partículas orientadas.

\section{INTRODUCTION}

Wood-cement boards are products widely used in civil construction, mainly in Asian and European countries, as exterior wall closing material. It is a similar product to particleboards, with differences related to the type of binder and pressing process, which in this case uses cement and pressing at room temperature (IWAKIRI, et al., 2015). This product shows advantages how: satisfactory physical e mechanical strength, relatively light when compared to pure cement due to the presence of wood and can be produced in the most varied sizes.

Oriented strand board (OSB) is a structural reconstituted panel manufactured by consolidating oriented wood strands with an exterior-type, waterproof resin under heat and pressure to make a reconstituted wood product with engineered properties. The OSB as in wood-cement boards exhibits even better weight and strength

FLORESTA, Curitiba, PR, v. 47, n. 3, p. 317 - 322, jul. / set. 2017

Rosa, T. S. da. et al.

ISSN eletrônico 1982-4688

DOI: $10.5380 /$ rf.v47i1.50789 
properties than plywood and has become the dominant structural sheathing material in North America obtaining significant growth in the structural wood based panel market (PAPADOPOULOS et al., 2006).

The combination between the properties of wood-cement board and OSB can be a way of improve some resistance faults in both types of panels for example those arising from particle geometry and orientation. It is a relatively important parameter that exerts great influence on the essential characteristics of the boards as the contact area between particles, mechanical properties and relative consumption of binder. On the other hand, the orientation of the particles gives to the OSB superior bending properties throughout the board when compared to the others boards type preserving dimensional stability (JULIANA et al., 2012).

Some studies trying to manufacture oriented wood-cement boards already were developed such as by Cabangon et al. (2002), Papadopoulos et al. (2006) e Del Menezzi et al. (2007). However, further research and testing is needed to ensure that this panels types meet proper end-use requirements and any applicable building codes (ARO, 2008), mainly in search to establish ideal parameters of manufacture such as wood species, particles geometry, cement/wood ratio, among others.

The selection of cement-compatible wood species is critical for successful production of wood-cement boards. Some species have demonstrated limited compatibility with cement because they contain excessive amounts of tannins and/or sugars that retard the setting of cement. Therefore, it is critical to select proper species or to remove the tannins and sugars before proceeding with board manufacture (ARO, 2008).

The wood-cement board production in general is less preferred from tropical hardwoods due to presence of chemical substances inhibitory how: sugar acids, sugars, and lignosulfonates, impermeable hydrates which inhibit or delay the setting of the cement binder. Also for this similar reason, commercial board production is generally not made from mixed wood raw materials. Only species which have been tested and found suitable are used, in general softwoods are more compatible with cement than hardwoods (FRYBORT et al., 2008).

On the other hand, some research with tropical hardwood species for example of Eucalyptus genus, found that this species has great potentiality to produce wood-cement boards with properties better than those with softwood species such as Pinus genus. Can be quoted research such as Iwakiri and Prata (2008), Sá et al. (2012) and Iwakiri et al. (2015) concluded that Eucalyptus species and mixtures can provide to wood-cement boards satisfactory properties.

This research aimed to manufacture oriented wood-cement boards using five Eucalyptus species and mixture between then, wood species from short rotation forest (7 years). To compare the effect of the orientation, boards with non-oriented particles were also produced and then evaluate the physical and mechanical properties according to competent standards.

\section{MATERIAL AND METHODS}

\section{Raw material}

Were used in this study, wood of Eucalyptus benthamii, Eucalyptus dunni, Eucalyptus grandis, Eucalyptus saligna e Eucalyptus urograndis from Rosário do Sul (RS, Brasil) with about 7 years old. Five trees per species were sampled, sectioned in logs, unfolded in blocks and later processed to generation the strands.

The strands were generated with nominal dimensions of $80 \mathrm{~mm}$ in length, $25 \mathrm{~mm}$ in width and $0.6 \mathrm{~mm}$ in thickness, in a rotary disk flaker with 4 knives. The strands were dried in a forced air oven at a temperature of $80{ }^{\circ} \mathrm{C}$ to obtain a moisture content of approximately $3 \%$ and then classified in a manual sifter with $9.52 \mathrm{~mm}$ openings for removal of fines.

The bonding agent employed was commercial grade Portland cement types CP II-Z-32R. Water was used to cement hydration and Calcium chloride $\left(\mathrm{CaCl}_{2}\right)$ to accelerate cement set during hydration.

\section{Boards production}

Were produced 21 wood-cement boards, resulting in 3 boards for each of 7 treatments (Table 1). Besides to use the species in pure form, boards were produced with the mixture between them, and still control treatment with Pinus taeda. The panels had dimensions of $48 \times 48 \times 1.2 \mathrm{~cm}$ and nominal specific mass of $1.2 \mathrm{~g} / \mathrm{cm}^{3}$. The cement/ wood/ water mass ratio used was $2.5: 1: 1$ and $2 \%$ of $\mathrm{CaCl}_{2}$ by weight of cement was used as an additive.

The classified strands were blended with cement in a concrete-mixer and then applied a solution of water and $\mathrm{CaCl}_{2}$ by sprinkling until complete hydration. The final mixture was divided into three parts, using the mass ratio 30:40:30 (surface/core/surface) to form a 3-layer board. The core layer of boards had the strands oriented perpendicular to the surface layers, with the exception of one treatments where the particles were randomly used throughout the panel. 
Table 1. Experimental design.

Tabela 1. Delineamento experimental.

\begin{tabular}{cc}
\hline Treatments & Species \\
\hline EB & Eucalyptus benthamii \\
ED & Eucalyptus dunnii \\
ES & Eucalyptus saligna \\
EU & Eucalyptus urograndis \\
PT & Pinus taeda \\
MO* & Mix oriented \\
MN* & Mix non-oriented \\
\hline$*$ Mixture containing $25 \%$ of each Eucalyptus species &
\end{tabular}

The mat was pressed at $4 \mathrm{MPa}$ using a hydraulic flat press and then stapled during 24 hours at room temperature. After pressing, the boards were then kept in conditioning for an additional 28 days to allow the cement to cure.

Physical and Mechanical Properties and Statistical Analysis

The consolidated boards were trimmed on the edge to eliminate low density regions and then cut the samples to determination of properties: density; water absorption after 24 hours; thickness swelling after 24 hours; strength to static bending parallel and perpendicular to the surface; and internal bond.

All physical and mechanical tests were carried out as part of the treatment of European standards: Density EN 323 (CEN, 2002d), Water Absorption and Thickness Swelling EN 317 (CEN, 2002b), Static Bending EN 310 (CEN, 2002a) and Internal Bond EN 319 (CEN, 2002c).

The results obtained in the tests were submitted to an analysis of variance and were subjected to an analysis of probability of nullity and a level of probability of error of $5 \%$.

\section{RESULTS}

\section{Physical properties of boards}

Table 2 shows the averages of density, water absorption after 24 hours and thickness swelling after 24 hours of boards.

Table 2. Physical properties of the boards.

Tabela 2. Propriedades físicas dos painéis.

\begin{tabular}{cccc}
\hline Treatment & $\begin{array}{c}\text { Density } \\
\left(\mathbf{g} / \mathbf{c m}^{\mathbf{3}}\right)\end{array}$ & $\begin{array}{c}\text { WA } \\
(\boldsymbol{\%})\end{array}$ & $\begin{array}{c}\text { TS } \\
(\mathbf{\%})\end{array}$ \\
\hline \multirow{2}{*}{ EB } & $1.02^{\mathrm{a}}$ & $23.62^{\mathrm{bc}}$ & $2.76^{\mathrm{a}}$ \\
& $(5.47)$ & $(8.60)$ & $(20.11)$ \\
ED & $0.98^{\mathrm{a}}$ & $26.76^{\mathrm{cd}}$ & $4.28^{\mathrm{b}}$ \\
& $(9.02)$ & $(17.69)$ & $(16.02)$ \\
ES & $1.01^{\mathrm{a}}$ & $19.38^{\mathrm{a}}$ & $2.70^{\mathrm{a}}$ \\
& $(5.97)$ & $(11.82)$ & $(21.86)$ \\
EU & $0.97^{\mathrm{a}}$ & $30.68^{\mathrm{e}}$ & $3.98^{\mathrm{ab}}$ \\
& $(4.91)$ & $(9.50)$ & $(18.18)$ \\
PT & $0.99^{\mathrm{a}}$ & $29.17^{\mathrm{de}}$ & $\left(170^{\mathrm{a}}\right.$ \\
& $(6.79)$ & $(15.19)$ & $3.56^{\mathrm{ab}}$ \\
MO & $1.00^{\mathrm{a}}$ & $21.71^{\mathrm{ab}}$ & $(11.88)$ \\
& $(4.93)$ & $(8.27)$ & $3.75^{\mathrm{ab}}$ \\
MN & $1.02^{\mathrm{a}}$ & $21.13^{\mathrm{ab}}$ & $(16.33)$ \\
\hline
\end{tabular}

WA= Water absorption after 24 hours; TS= Thickness swelling after 24 hours.

Averages followed by the same letter in the same column do not differ statistically by the Tukey test at the 5\% of probability level.

Values in parentheses refer to the coefficient of variation in percentage.

The density averages of boards varied in the range of $0.97 \mathrm{~g} / \mathrm{cm}^{3}$ to $1.02 \mathrm{~g} / \mathrm{cm}^{3}$ for the different treatments. The values were lower than the nominal density of $1.2 \mathrm{~g} / \mathrm{cm}^{3}$, this variation of density is expected due to the losses of strands that occur during the steps of manual manufacturing process of boards and the return in thickness after the pressing. The values obtained are below the density of commercial panels, according to Standard IS (NSBI, 1995) is $1.250 \mathrm{~g} / \mathrm{cm}^{3}$.

FLORESTA, Curitiba, PR, v. 47, n. 3, p. 317 - 322, jul. / set. 2017

Rosa, T. S. da. et al.

ISSN eletrônico 1982-4688

DOI: $10.5380 /$ rf.v47i1.50789 
The averages of WA varied of $19.38 \%$ until $30.68 \%$ and can be observed that there were not significant statistical differences between the treatments ES, MO and MN that showed the less values. Except for treatments ED, EU and PT all others arrived the minimum requirement of 25\% stipulated by Standard IS 14276 (NSBI, 1995) standard.

The TS values varied on the range of $2.70 \%$ to $4.28 \%$, and there were not significant statistical differences between most treatments, however, ED showed a highest trend to swelling when compared with EB, ES and PT.

Mechanical properties of boards

Table 3 shows the averages of internal bond, modulus of rupture and elasticity obtained by parallel and perpendicular static bending of boards.

Table 3. Mechanical properties of the boards.

Tabela 3. Propriedades mecânicas dos painéis.

\begin{tabular}{cccccc}
\hline Treatment & $\begin{array}{c}\text { IB } \\
(\mathbf{M P a})\end{array}$ & $\begin{array}{c}\text { MOR } \| \\
(\mathbf{M P a})\end{array}$ & $\begin{array}{c}\text { MOE } \| \\
(\mathbf{M P a})\end{array}$ & $\begin{array}{c}\text { MOR } \perp \\
(\mathbf{M P a})\end{array}$ & $\begin{array}{c}\text { MOE } \perp \\
(\mathbf{M P a})\end{array}$ \\
\hline \multirow{2}{*}{ EB } & $0.11^{\mathrm{ab}}$ & $6.96^{\mathrm{a}}$ & $2295.12^{\mathrm{a}}$ & $3.66^{\mathrm{bc}}$ & $820.39^{\mathrm{bc}}$ \\
& $(26.87)$ & $(31.28)$ & $(26.57)$ & $(17.16)$ & $(18.54)$ \\
ED & $0.03^{\mathrm{cd}}$ & $2.46^{\mathrm{c}}$ & $687.56^{\mathrm{d}}$ & $2.67^{\mathrm{c}}$ & $553.25^{\mathrm{c}}$ \\
& $(16.65)$ & $(37.30)$ & $(26.55)$ & $(26.97)$ & $(34.96)$ \\
ES & $0.09^{\mathrm{ab}}$ & $5.11^{\mathrm{b}}$ & $1947.67^{\mathrm{ab}}$ & $2.92^{\mathrm{bc}}$ & $1324.13^{\mathrm{ab}}$ \\
& $(20.57)$ & $(38.10)$ & $(22.83)$ & $(30.86)$ & $(23.58)$ \\
EU & $0.03^{\mathrm{d}}$ & $4.37^{\mathrm{bc}}$ & $1056.17^{\mathrm{cd}}$ & $2.93^{\mathrm{c}}$ & $504.96^{\mathrm{c}}$ \\
& $(14.97)$ & $(26.72)$ & $(34.03)$ & $(26.21)$ & $(31.68)$ \\
PT & $0.07^{\mathrm{ab}}$ & $7.12^{\mathrm{a}}$ & $2041.21^{\mathrm{ab}}$ & $5.71^{\mathrm{a}}$ & $1116.13^{\mathrm{ab}}$ \\
& $(18.83)$ & $(26.44)$ & $(26.99)$ & $(21.50)$ & $(17.75)$ \\
MO & $0.06^{\mathrm{bc}}$ & $5.45^{\mathrm{ab}}$ & $1871.45^{\mathrm{ab}}$ & $2.96^{\mathrm{c}}$ & $560.41^{\mathrm{c}}$ \\
& $(21.73)$ & $(42.23)$ & $(30.72)$ & $(31.91)$ & $(36.35)$ \\
MN & $0.12^{\mathrm{a}}$ & $3.44^{\mathrm{bc}}$ & $1479.89^{\mathrm{bc}}$ & $5.05^{\mathrm{ab}}$ & $1562.60^{\mathrm{a}}$ \\
& $(19.98)$ & $(47.01)$ & $(34.14)$ & $(32.97)$ & $(28.02)$ \\
\hline
\end{tabular}

$\mathrm{MOR}=$ Modulus of rupture; $\mathrm{MOE}=$ Modulus of elasticity; $\mathrm{IB}=$ Internal bond

$\|=$ Parallel; $\perp=$ Perpendicular;

Averages followed by the same letter in the same column do not differ statistically by the Tukey test at the $5 \%$ of probability level.

Values in parentheses refer to the coefficient of variation in percentage.

The IB values varied on the range of $0.03 \mathrm{MPa}$ to $0.11 \mathrm{MPa}$, in comparison between Eucalyptus species, the boards produced with ED and EU showed lower internal bond results that the other species. It can be observed that had significant differences between the treatments composed with mix species.

In general way, none treatments reached the requirements to internal bond of standards NSBI (1995) and ISO (1987), that estipulate minimum values of $0.40 \mathrm{MPa}$ and $0.50 \mathrm{MPa}$, respectively

The averages ranged from 2.46 MPa to $6.96 \mathrm{MPa}$ for MOR \| and 687.56 MPa to 2295.12 MPa for MOE ॥, respectively. None treatments met IS 14276 (NSBI, 1995) and ISO 8335 (ISO, 1987) requirements, which specifies $9 \mathrm{MPa}$ to MOR and $3000 \mathrm{MPa}$ to MOE.

The low strength observed in MOR $\|$ and MOE $\|$, was confirmed in MOR $\perp$ and MOE $\perp$ which showed averages that varied on the range of 2.67 MPa to 5.71 MPa and 504.96 MPa to $1562.60 \mathrm{MPa}$ for both properties.

\section{DISCUSSION}

\section{Boards physical properties}

In comparison between treatments, the EU and PT obtained the highest absorption values. For treatments composed by species mixture (MO and $\mathrm{MN}$ ), there was not statistical differences between them, it can be affirm that an orientation of strands did not influence the property in question.

The WA values are above those found by Iwakiri and Prata (2008), that working with Eucalyptus grandis and Eucalyptus dunnii in wood-cement boards obtained WA in the range of $14.27 \%$ to $20.34 \%$. On the other hand, the averages were consistent with the values obtained by Del Menezzi et al. (2007) of 24.30\% to $33.30 \%$ for oriented wood-cement boards produced with Pinus taeda.

The TS results were consistent with the values obtained by Iwakiri and Prata (2008), whose averages varied of $1.69 \%$ until $4.83 \%$. All values of TS obtained in this study showed below to results obtained by Del Menezzi et al. (2007), that varied between $9.00 \%$ to $10.50 \%$. 
According Amiandamhen and Izekor (2013), this high dimensional stability occurs due the presence of more irregular void spaces in strand board which allows internal swelling. In this way, the particle geometry together wood-cement ratio can have influenced the physical properties of the boards, because, boards produced from lower wood-cement ratios and bigger particles (strand-type), difficult to compact and are not completely umected by cement which resulted in lower bonding and less dimensional stability.

Mechanical properties of boards

The internal bond of boards was influenced by particles orientation, so that, MN showed higher IB values when compared with MO. On the other hand, had not differences with EB, ES and PT, in this way, the particles orientation may have not directly influenced the IB results, but another productive process parameters.

Very low IB values also were found by Dell Menezzi et al. (2007). These authors obtained IB averages of $0.03 \mathrm{MPa}$ and explained this fact to strands geometry and low wood-cement ratio. In this study, the wide strands and the cement proportion also can have influenced in IB, because the low cement amount was not sufficient to cover the all strands that are wider and then present larger surface area.

For both MOR \| and MOE \|, the boards produced with EB obtained the highest values between the Eucalyptus species. However, statistical differences were not found between ES, MO and PT, indicating that with the species mixture can be obtained boards with properties similar to Eucalyptus species boards and Pinus boards. The MOR || and MOE || values were lower than those observed by Okino et al. (2004) and, also lower than those found by Iwakiri et al., (2015), however, are in conformity with those made by Dell Menezzi et al. (2007), certainly due to the differences between the particle dimensions.

To MOR $\perp$ and MOE $\perp$ values, the PT (control specie) obtained values significantly higher than ED, EU and MO, it can be explained because the density of Pinus taeda wood is lower than Eucalyptus species, in this way, it is likely that these panels obtained a higher compression ratio, thus, the particle mattress is better compacted during pressing, promoting a greater contact between particles, which contributes to the resistance of boards to bending strength.

Other case observed, is the fact that MN presented MOR $\perp$ and MOE $\perp$ averages higher than MO. Which can be assigned to orientation of the outer layers particles in OSB, this improve sensibly the static bending and stiffness properties in parallel direction, however, there is a reduction in the perpendicular (MACNATT et al, 1992; CABANGON et al. 2002; STÜRZENBECHER et al., 2010).

\section{CONCLUSION}

The results obtained in present study allowed to conclude that:

- The wood of Eucalyptus species presents potential for use in cement-wood panels, requiring only some adjustments in composition of the boards in order to meet the quality standards.

- The mixture of species demonstrated that can be produce boards with similar properties to those boards produced with pure species.

- The use of strands to produce wood-cement boards did not contribute to obtain satisfactory properties as in OSB traditional.

- The orientation of the particles may influence some mechanical properties, but not the physical properties.

- Wood-cement ratio can have affected the physical and mechanical properties of oriented wood-cement boards.

- Studies are necessary to determine the best geometry of particles to make feasible to oriented wood-cement board manufacture.

\section{REFERENCES}

AMIANDAMHEN, S. O.; IZEKOR, D. N. Effect of wood particle geometry and pre-treatments on the strength and sorption properties of cement-bonded particle boards. Journal of Applied and Natural Science, v. 5, n. 2, p. 318-322, 2013.

ARO, M. Wood strand cement board. 11th International Inorganic-Bonded Fiber Composites Conference. Annals, Madrid, p. 169-179, 2008.

FLORESTA, Curitiba, PR, v. 47, n. 3, p. 317 - 322, jul. / set. 2017. 
CABAngon, R. J.; CUNNInghaM, R. B.; EVANS, P. D. Manual Strand Orientation as a Means of Improving the Flexural Properties of Wood-Wool Cement Boards in the Philippines. Forest Products Journal, v. 52, n. 4, p. 53-59, 2002.

DEL MENEZZI, C. H.; CASTRO, V. G.; SOUZA, M. R. Production and properties of a medium density woodcement boards produced with oriented strands and silica fume. Maderas. Ciencia y Tecnología, v. 9, n. 2, p. 105-115, 2007.

EUROPEAN COMMITTEE FOR STANDARDIZATION - CEN. EN 310: Determination of modulus of elasticity in bending and of bending strength. Bruxelas, 2002a.

EUROPEAN COMMITTEE FOR STANDARDIZATION - CEN. EN 317: Determination of swelling in thickness after immersion in water. Bruxelas, $2002 \mathrm{~b}$.

EUROPEAN COMMITTEE FOR STANDARDIZATION - CEN. EN 319: Perpendicular tensile strength of particleboards and fiberboards. Bruxelas, 2002c.

EUROPEAN COMMITTEE FOR STANDARDIZATION - CEN. EN 323: Wood based panels - Determination of density. Bruxelas, 2002d.

FRYBORT, S.; MAURITZ, R.; TEISCHINGER, A.; MÜLlERA, U. Cement bonded composites - a mechanical review. BioResources, North Carolina, v. 3, n. 2, p. 602-626, 2008.

INTERNATIONAL ORGANIZATION FOR STANDARDIZATION - ISO. 8335: Cement-bonded particleboards - Boards of Portland or equivalent cement reinforced with fibrous wood particles, Genebra, 1987.

IWAKIRI, S.; PRATA, J. G. Utilização da madeira de Eucalyptus grandis e Eucalyptus dunnii na produçao de painéis de cimento-madeira. Cerne, v. 14, n. 1, p. 68-74, 2008.

IWAKIRI, S.; TRIANOSKI, R.; CUNHA, A. B.; PRATA, J. G.; HARA, M.; BILA, N. F.; ARAÚJO, R. D. Propriedades tecnológicas de painéis cimento-madeira produzidos com partículas de eucalipto. Revista de Ciências Agroveterinárias, v. 14, n. 3, p. 217-223, 2015.

JUliANA, A. H.; PARIDAH, M. T.; RAHIM, S.; NOR AZOWA, I.; ANWAR, U. M. K. Properties of particleboard made from kenaf (Hibiscus cannabinus L.) as function of particle geometry. Materials and Design, v. 34, p. 406-411, 2012.

MACNATT, J. D.; BACH, L.; WELLWOOD, R. W. Contribution of flake alignement to performance of strandboard. Forest Products Journal, Madison, v. 42, n. 3, p. 45-50, 1992.

NATIONAL STANDARDS BODY OF INDIA - NSBI. IS 14276: Cement bonded particle boardsSpecification, India, 1995.

OKINO, E. Y.; SOUZA, M. R.; SANTANA, M. A.; ALVES, M. V.; SOUSA, M. E.; TEIXEIRA, D. E. Cementbonded wood particleboard with a mixture of eucalypt and rubberwood. Cement \& Concrete Composites, v. 26, n. 6, p. 729-734, 2004.

PAPADOPOULOS, A. N.; NTALOS, G. A.; KAKARAS, I. Mechanical and physical properties of cementbonded OSB. Holz als Roh und Werkstoff, v. 64, n. 6, p. 517-518, 2006.

SÁ, V. A.; BUFALINO, L.; ALBINO, V. C.; CORRÊA, A. A.; MENDES, L. M.; ALMEIDA, N. A. Mistura de três espécies de reflorestamento na produção de painéis cimento-madeira. Árvore, v. 36, n. 3, p. 549 - 557, 2012.

IWAKIRI, S.; TRIANOSKI, R.; CUNHA, A. B.; PRATA, J. G.; MASSAYUKI, H.; BILA, N. F.; LUIS, R. C. G.; ARAÚJO, R. D. Technological properties of cement-wood panels produced with eucalypt particles. Revista de Ciências Agroveterinárias, v. 14, n. 3, p. 217-223, 2015.

STÜRZENBECHER， R.; HOFSTETTER， K.; BOGENSPERGER， T.; SCHICKHOFER, G.; EBERHARDSTEINER, J. Development of high-performance strand boards: engineering design and experimental investigations. Wood Science Technology, v. 44, p. 13-29, 2010. 